\title{
IMPROVISACION E IMPROVISADORES EN LA GALICIA DEL SIGLO XVIII
}

\author{
María Rosa SAURIN DE LA IGLESIA
}

Universidad de Urbino

Entre los papeles de Comide existentes en el Archivo Histórico del Reino de Galicia se conserva un curioso manuscrito titulado Certamen poético al asunto que dirá este papel..., que a su interés intrínseco anade el de haber llamado la atención de uno de los personajes más sobresalientes de la Ilustración gallega hasta el punto de ser guardado por él junto con otras muestras poéticas. Cornide está esperando todavía la biografía que se merece y para la que no escasean materiales -como que quizá sea más bien la variedad de los que se ofrecen y la multiplicidad de los aspectos que habría que abordar en ella lo que amilane a los investigadores, retrayéndolos de una tarea que, como quiera, resarcirá al fin con creces los esfuerzos requeridos. Es bastante lo que se sabe-aunque sea de manera asistemática- acerca del pensamiento económico del prócer coruñés o de su labor arqueológica mientras que una buena parte de su actitud ante las bellas letras sigue quedando en la sombra, y este vacío es tanto más lamentable por establecer una solución de continuidad entre planos complementarios de la personalidad de todo ilustrado que no es lícito escindir, merecedores por tanto de pareja consideración pues es bien sabido que el siglo XVIII no hacía -como el nuestro- compartimientos estancos entre los varios ramos del saber. Por esa razón ningún miembro del estamento privilegiado dejó de llevar hasta sus últimas consecuencias el engagement contraído con las luces, sirviéndose de todas las formas de expresión y de todas las actividades del espíritu para exaltar un ideal y un modelo humano de nuevo cuño. 
Es conocido el lugar preferente que entre esas actividades ocupó la poesía, utilizada no pocas veces -y sin escándalo de nadie, por cierto- como instrumento persuasivo o de mera comunicación, en toda una gama de registros que van de lo fútil a lo trascendente'. Por las pocas muestras de que disponemos hasta ahora, y ateniéndonos al modo de juzgar de la crítica tradicional, sabemos que Cornide pagó su tributo a ese modo *menor» de entender el quehacer poético, produciéndose con una llaneza y una espontaneidad que casan bien con el medio de expresión escogido, esto es, con el gallego de la comunicación cotidiana, lengua carente entonces de dignidad literaria ${ }^{2}$. La revalorización de nuestro siglo XVIII -tal como viene siendo entendida en estos últimos tiempos- invita a revisar los motivos por los que todo un Don José Cornide -y con él tantos de sus contemporáneos- podía conciliar tranquilamente los muchos quilates de su bagaje cultural con un concepto de poesía que no despierta hoy sino desprecio, llegando por añadidura a dedicarle no pocos de sus ocios. Pues bien, este manuscrito puede servir de clave para una primera aproximación al problema, eslabonando los gustos y aficiones de nuestro hombre con las muestras de ingenio de amigos y conocidos que se complacía en conservar entre sus cartapacios por considerarlas dignas de atención.

Nos hallamos ante un cuadernillo manuscrito de treinta y dos páginas, fechado en 6 de enero de 1759 , obra de cierto Fray S.T.V., extremeño y probablemente franciscano, según se vishumbra en varias alusiones ${ }^{3}$, que gozaba, al parecer, de algún renombre como repentizador y que se complace en dejar constancia escrita de sus dotes, consideradas precisamente en aquella época como señal de una peregrina exquisitez lindante con el genio. El siglo XVIII conoció una gran boga del in promptu y exaltó la facultad de repentizar como expresión máxima del talento poético. La espontaneidad de las emociones así exteriorizadas, la prontitud en captar un flujo de ideas e imágenes canalizándolas con el sabio dominio de la técnica métrica, tal como se observan en sus mayores exponentes, tiene mucho de espectáculo teatral y ronda además de cerca los linderos del raptus. Los grandes ídolos del Siglo Ilustrado -y Metastasio entre

Joaquín ARCE, La poesá del Siglo Ilustrado, Alhambra, Madrid, 1980, pág. 31

M. MURGUIA, "Don José Cornide y sus versus en gallego", en Boletín de la Reat Acade-

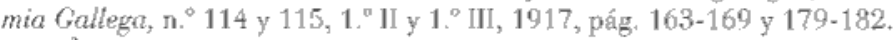

${ }^{3}$ “... yo, que en todo soy pequeño...": f. 1 ; “".. el menor, aunque el más obligadio..." vto.; "... dicen los Sres. Theólogos, pero los que no lo somas..." "f. 10 vto., etc.

Bruno GENTLLI, "Cultura dell'improvviso. Poesia orale colta nel Settecento italiano e poesia greca dell'età arcaica e classica", en Quaderni Urbinati di Cultura Classica, Nuova Serie, 6 , 1980, pág. 24-33. Gifr. Luis Gil, Los antiguos y la "inspiración poéticu*, Madrid, Guadarrama, 1966. 
ellos- rendían pleitesía al fenómeno de la improvisación poética, enraizado en una tradición clásica que remite a la posesión divina de los rapsodas griegos y que contribuyó a reforzar la persuasión de superioridad implícita en aquella facultad. Precisamente al enorme prestigio de este modo de poetizar se debió el que triunfase y se extendiese en ambientes y situaciones tan distantes ya del pathos originario que de él no conservaban sino la facilidad mecánica de la expresión cn metro como sucedáneo del soplo del genio. Pero, aun en esa versión reducida, el fenómeno hizo furor durante algún tiempo y tras su maravillosa estela corrieron hechizados infinitos epígonos, con todos los matices que median entre pose y autenticidad.

La evocación del repentizador que Mor de Fuentes había visto actuar en Paris ${ }^{5}$ induce a reflexionar sobre lo mucho que esa moda de la improvisación tenía de performance convencional: en la descripción de las idas y venidas del repentista ante el auditorio, de sus aspavientos, alaridos y contorsiones, se trasluce a las claras el profundo desencanto que aquel fenómeno de moda produjo en un buen entendedor, para quien todo aquel «fraguar diálogos y enhilar consonantes» evidenciaba simplemente un oficio, el dominio de una técnica, que no el entusiasmo apolíneo. Pero, con todo, aun refrenada la grandiosidad originaria de la improvisación, domesticada su patética tensión psicofísica, domeñada la «locura o posesión del genio, la improvisación poética siguió ejerciendo importantísima función social y conectiva, de circunstancias ya que no surgida del aura divina. El mismo Mor de Fuentes admite la importancia de esa función comunicativa de la poesía al uso recordando las cualidades de su padre, "repentista de boca y sumamente ejecutivo* y por ello indispensable «coplero de las ocurrencias del país ${ }^{6}$. Por el jesuita Bettinelli sabemos que en la Italia de su tiempo no había boda, profesión religiosa o doctorado que no llevase aparejada una actividad torrencial de los repentistas, asoldados «al pari de' falegnami, de' pittori, degli stuccatori e de' macchinisti, col solo divario che aveano paga più discreta di tutti gli altri ${ }^{7}$. Lo mismo afirmaba Baretti en sus Lettere familiari, y unas páginas curiosas del Cura de Fruime dan fe de la difusión de aquella moda cn la Galicia de su tiempo ${ }^{9}$. En una palabra, no había fiesta casera u oficial

\footnotetext{
5 J. MOR DE FUENTES, "Bosquejillo de la vida y escritos de D. ...", en Memorias de la época de Fernando VII, B.A.E., Madrid, 1957, pág. 409 a.

' Ibid, pág. 428 a.

7 Saverio BETTINELLI, Lettere inglesi e altri scritti, Laterza, Bari, 1930, pág. 86.

s Laterza, Bari, 1912, pág. 91.

? Diego Antonio CERNADAS Y CASTRO, El Junipero jovial y el Donado retozón, en Obras en prosa y verso del Cura de Fruine, D. ..., Ibarra, Madrid, 1780, V, pág. 307-320.
} 
en la que la poesía dejase de representar papel principalísimo, al par de un rito placentero consumado en la fraternal compañía de sus adeptos.

El texto del certamen conservando por Comide se inscribe en este género de celebraciones domésticas y surge un día de Reyes en torno a una bien servida mesa, la del gobemador de los Estados de Monterrey Don Jospeh García Peñalosa, funcionario de alta categoría al servicio de la Casa de Alba, extremeño arribado a los dominios de su Señor en Galicia tras haber desempeñado otros cargos administrativos de importancia en Trujillo, Toledo, Soria y varios puntos más de España. Los administradores o gobernadores de los Estados nobiliarios solían clasificarse entre los miembros de la hidalguía más decididos a labrarse un porvenir en una carrera de alta consideración, casi a la par con la administración del Estado e incluso dotada de mayor porder, si no de tanto honor, en razón de la proximidad habitual del Señor, fuente de todo privilegio. A esa categoría pertenecía, por ejemplo, Don José de Isla Pis de la Torre, padre del famoso autor del Fray Gerundio, corregidor a las órdenes de los Condes de Altamira en tierras leonesas. Reclutados a través del sólido entramado de la solidaridad familiar, de la recomendación -0 , como se decía entonces, del «empeñon-, estos funcionarios señoriales si no siempre poseían una cultura universitaria propiamente dicha cran, en todo caso, letrados fieles y eficientes, a menudo autodidactas, formados quizá como practicones ${ }^{10}$. Todo en su tren de vida y pensamiento asimilaba a estos altos funcionarios de la administración señorial a la aristocracia cn cuya órbita se movían y de la que eran brazo ejecutivo, reflejando el ideal de refindaniento propio de aquélla en un tomo menor muy acep ${ }^{-}$ vable. En cl ápice de la liturgia social que exalta los valores de los grupos dominantes descollaban las "academias", como se llamaba cntonces a los cenáculos literarios y artísticos que con mayor o menor constancia y pericia cultivaban los ideales del siglo. En ellas podía manifestarse sin rebozo, con la seguridad de producirse inter pares, la irreprimible fidelidad a las musas propia de los ánimos selectos, tildada empero por el vulgo como «vicio o travesura de ingenio ${ }^{11}$ indigna de graves y sesudos varones. Cierto es también que contra la extendida convicción de que shacer coplas no es diversión de gente de juicio sino de truhanes y bufones» "2 no faltaron intrépidos paladines dispuestos a romper lanzas a favor de la poesía no ya sólo en el terreno práctico sino incluso en el de la teoría literaria: entre ellos el jesuita Burriel, que abría su famoso Com-

14. De los que recibían de abogados en La Coruña se decía que "por costunbre, o por tolerancia, o por equivalencia los llaman licenciados": CERNADAS, Obros..., cit. 1779, IV, pág. 187.

"CERNADAS, up. cii, V, pág. 333.

12 Ibid., pág. 127. 
pendio del arte poética reivindicando la importancia del quehacer poético, que no sólo no merecía ser considerado «ocupación indiferente de gente desocupada u ociosa, sino que se debe mirar la facultad misma como uno de los medios más eficaces para hacer a los hombres sociables ${ }^{13}$.

La afición a la poesía amalgama, pues, a sus entusiastas dondequiera que se hallen. Los centros de población importantes podían permitirse el lujo de sostener de manera estable tertulias literarias proyectadas hacia el quehacer poético: así Santiago, por su solera universitaria, o La Coruña, donde existía en la primera mitad del siglo una academia de poetas organizada en toda regla y animada por el elemento militar ${ }^{14}$. Pero, con no menos fervor, otros numerosos secuaces de Apolo diseminados por todo el Reino aplicaban sus mejores afanes al incomparable solaz de la creación poética sin acobardarse poco ni mucho ante el sambenito de ligereza que llevaban aparejadas sus aficiones. En el Cura de Fruime, por ejemplo, se hallan repetidas alusiones a esas prevenciones vulgares y otras tantas recomendaciones "para que no se aterren algunos poetas pusilánimes con aquel coco y fantasmón que suelen poner algunos Catones preciados de sesudos, que ponderan que el hacer versos es propio de maniáticos... ${ }^{15}$. Es precisamente en las casas solariegas y en las innumerables ocasiones que el ritmo de las estaciones y las solennidades familiares ofrecía en ellas a la vida social -vendimias y carnavales, bodas y bautizos, romerías y partidas de cazadonde se desarrolla vigoroso un culto de la poesía en todo opuesto al consumo individual, solitario y puramente libresco a que parece haberse reducido en nuestros días el trato con las musas. Se producía allí entonces una poesía hoy completamente desconocida de la crítica -si no despreciada por ella- y sin embargo interesantísima para el historiador deseoso de aproximarse a un mundo desaparecido.

En el manuscrito que nos ocupa podemos observar cómo se produce el proceso de creación poética precisamente en una de esas ocasiones pintiparadas para que la pasión versificadora se apoderase de todo el mundo: de sobremesa, la insistencia de la anfitriona obliga a Fray S.T.V. a exhibir sus habilidades, instaurándose al instante una sintonia perfecta entre los comensales de tal manera que el repentizador, atemorizado al principio por su momentánea falta de inspiración, no tarda en deslumbrarlos a todos con el chisporroteo de su artille-

13. Antonio BURRIEL, Compendio del arte poética, Madrid, 1757, pág. 1.

164.

" CERNADAS, op. cit, V, pág. 321; la noticia es recogida por MURGUIA, loc. cit., pág. is lbid., pág. 333. 
ría poética. Tanto el fraile repentizador como los dos «religiosos condecorados» que compiten con él -uno de los cuales parece ser jesuita-, los abades -es decir, párrocos, según la denominación típica de la Galicia meridional- de Flariz y Vilamaior y, en fin, el resto de los presentes -hidalgos todos ellos de posición sobresaliente-aparecen condicionados por un patrón cultural similar, lo que es como decir que se han formado en los cánones de la escolástica que triunfaba en las aulas y que, fuera de ellas, concedía un prestigioso barniz a los elementos cultos de la sociedad. En esa mismá órbita han de incluirse las damas, cuyo importante papel en los círculos literarios de la Europa ilustrada es de sobra conocido y a cuya atención -no menos que a la de todos los que ignoraban la lengua de las aulas-iban dirigidos proyectos de divulgación cultural tan ambiciosos como el Cultivo racional de Fray Ignacio Gómez Losada ${ }^{16}$.

Lo curioso es que en este entretenimiento casero se observan entre los congregados alrededor de una mésa los mismos signos distintivos que en el raptus de los aedos griegos o de los más prestigiosos improvisadores italianos del siglo XVIII: desasistido al pronto del aura divina al repentizador no se le ocurre nada prara satisfacer la petición de la anfitriona; y es que, a su parecer, la extraordinaria tensión psicofísica de actividades poéticas anteriores y repetidas había acabado por menoscabar su estro, dejando su $*$ Parnaso infecundo, bravío y lleno de malezas». De manera análoga, también el joven Metastasio se había percatado de que la temeraria insistencia en la repentización tería más de dañosos que de positivo -ya fucra para su salud, ya cn orden a la reflexión racional que dehe guiar al poeta ${ }^{17}$ - con lo cual había acabado por abancionarla. Y, precisamente, a allanar ese terrible escollo de la falta de inspiración es a lo que tendía la invocación a la divinidad con que principiaban su actuación los improvisadores tanto de la antigüedad como del Siglo Ilustrado ${ }^{18}$. Pues bien, en este entretenimiento casero el procedimiento seguido por nuestro fraile es en todo paralelo el modelo clásico aunque su apelación sea más de tejas abajo y vaya dirigida a las señoras de la casa, paisanas y amigas, bajo cuya benevolencia y

16. Cultivo racional, diálogo entre Curoso y Desengaño, en que con nueva modo de Erudicción Philosophica y Doctina sutil, o Scotica, instruye Desengaño a Cutioso, para hacer fértit y fecundo su entendimiento, Antonio Sanz, Madid, 1743. La obra, que se vendía no sólo en Madrid sino tambien en Mellid, Santiago y La Graña, aparecia en español "para que hombres y mujeres que no sabían otra lengua no hallasen menos la Latina para cultivaf su entendiniento y los que se hallan con talento para las sublimes materias y les falta oportunidad para cursar las aulas hallasen suplemento suficiente de las Philosophicas noticias.

Pietro METASTASIO, "Carta 492 a Francesco Algarott", Viena, 1. VIH. 1751, en Tutte le opere, ed. de B. Brunelli, Milano, 1951, III, pág. 659 y sigs.

GENTILI, op. cit., pág. 27-28. 
protección se apresta a entrar en liza. La analogía esencial de tales improvisaciones caseras con las de los auténticos rapsodas queda bien trazada por el Cura de Fruime al describir a un colegial franciscano de Tuy, participante en una de ellas, «tan suspenso y enagenado que teniendo delante la vianda no le decía siquiera esta boca es mía», señal inequívoca-dada la edad, el momento y la suculencia de los manjares- del arrebato de aquella «enfermedad [...] que se llama furor apolíneo, o alferecía mental, en la que a la hora de comer se sube el raptus poético a la cabeza y, sofocados los sentidos, se está el paciente infatuado, convertido en un pegaso mudo, tascando el freno, sin probar otro bocado, y teniendo delante el pesebre lleno se le quedan el estómago y los cascos vacíos por divertir y saborear a otros con un par de equívocos mal digeridos $x^{19}$.

Por más que todo el certamen se desarrolle entre bromas y veras, el poeta exhibe -como en el caso de la improvisación arcaica- el convencimiento pleno de una excelsitud que lo coloca entre los elegidos; se considera depositario de un patrimonio cultural singular, de una especial habilidad, de unas técnicas compositivas no menos excepcionales que su dominio de la memoria; se siente superior, en una palabra, a sus émulos los «anticoplizantes» que, sin fe en la poesía, no le llegan a la suela del zapato, aun con toda su calidad y sus títulos académicos a cuestas. De una sola cosa les es deudor: de algo tan importante como la atmósfera de receptividad que viene a crearse de inmediato por obra y gracia de la complicidad de un auditorio capaz de captar su mensaje. Esa presencia colectiva de entendedores y aficionados es condición indispensable para poetizar in promptu. Y así, aunque estemos aquí muy lejos de la milagrosa posesión del numen, la situación es en todo análoga al ritual establecido y no resta nada a la perfecta seriedad de un estado emotivo de entusiasmo recíprocamente compartido, ya que, en efecto, sólo la convicción de saberse comprendido en pleno permite al repentizador enfrascarse en su arte de manera tan prolongada y exclusiva.

Lo que sigue a continuación está ya del todo condicionado por las características de la poesía en la España de mediados del siglo XVIII. Son precisamente los valores dominantes en el universo cultural del poeta y de su auditorio lo que caracteriza e inspira el tono y el meollo de las improvisaciones. El desmedido prurito polémico que se observa en ellas, el gusto por un aparatoso conceptismo, el tono menor, lo burlesco derrochado sin tasa, son elementos tan obsesivamente presentes que no sólo rompen sin remedio y por su propia naturaleza la tensión patética de la improvisación de cuño clásico sino que qui-

19 Obras..., cit., V. pág. 320. 
zá dificulten irremediablemente el in promptu, de cualquier nivel que sea, como inoportunas chinas sembradas en el camino real del rapsoda. El estado semihipnótico, de íntima comunión entre el repentizador y su auditorio, que se obtenía en la improvisación tout court por vía irracional y emotiva, deja paso aquí a un cerebralismo desatado y a la vis polemica de unos versos construidos como si fueran silogismos, arma arrojadiza con que demoler al adversario y exaltar a un tiempo la propia pericia, como exigía la buena tradición de las disputationes.

Las composiciones que enorgullecen al fraile repentizador son instantáneas surgidas de un humorismo de filiación escolástica, no sólo por lo que de fidelidad al aprendizaje estudiantil tiene la observancia de la mecámica del verso sino también - principalmente- porque todo en el certamen recuerda actitudes y resabios de las aulas, ya fueran los ejercicios literarios hechos en clase, ya los desafíos, dicterios e impugnaciones con que -como deploraba Feijoo- se hundían las aulas a gritos, y que formaban parte del más castizo estilo académico del tiempo. Experiencias comunes de este tipo ligaban sin duda a los contendientes -a pesar de la diferencia de edad que se adivina entre ellos- y se reflejan en la polémica agresividad de sus décimas en las que, como en el ambiente escolar, saltan sin transición de la rivalidad regional y de hábito a los equívocos más o menos picantes, de las sutilezas tcológicas a la irreverencia con el marbete $\alpha$ a lo divino», de los personalismos y mordacidades de dudoso gusto a Ios retruécanos y agudezas más desatinados para rematar al cabo en una cascada de charadas. El todo muy en la línea de aquel desenfado en que eran maestros Eugenio Gerardo Lobo, León Marchante y el Cura de Fruime, que ahondaba sus raíces en Quevedo y Góngora y que había de seguir haciendo furor hasta los días postreros del Siglo Ilustrado, a despesho de reformas y reformadores.

Con su comportamiento literario muestros repentizadores demuestran ignorar en absoluto la campaña antibarroca emprendida por Feijoo un cuarto de siglo antes, no menos que las opiniones análogas de Sarmiento, en veinte años posteriores a aquéllas, y ostentan preferencias decididas hacia actitudes poéticas de antigua raigambre. Actitudes que, datadas y todo, se resistían a desaparecer, como acredita el que en fecha tan tardía como 1795 hallase favor vodavía el panegírico de la armonía verbal y tal como lo había entendido Rengifo casi dos siglos antes. En ese año salía en su defensa un anónimo articulista del "Diario de Madrid» observando: «En el día se declama mucho contra la glosa, la reputan composición de retruécanos, de puro consonante, pábulo de las almas baxas y ensayo de poetas a la moda...». Y, sin embargo, aunque "algunos hacen indirectamente desprecio y mofa de el verso y de la disposición armóni- 
ca de las palabras», en su opinión no dejaba de constituir «una extravagancia pretender desterrar de la poesía un género de composición material armónico» ${ }^{20}$. Precisamente por aquellos mismos días la defensa de la musicalidad en poesía llevaba a Pardo de Andrade y a Fernández de Rojas a intentar codificar los espacios sonoros de la rima y el verso libre y a polemizar sobre la nueva sensibilidad de lo sencillo, realzada a través precisamente de esos medios ${ }^{21}$. Pues bien, Rengifo, sin sospechar los inconvenientes de la fidelidad secular a su manual - que había enseñado la técnica métrica a una generación de españoles tras otra. sin perder vigencia- afirmaba convencido: «Suelen las glosas, quando son perfectas, dar particular contento, y no sólo quando se glosan cosas graves, pero aun quando el texto es de algún dicho gracioso» ${ }^{22}$. En pleno siglo XVIII esa misma placentera sensación seguía dando que hacer a toda una caterva de poetas que por seguir aferrándose a aquella autoridad se aseguraba el desprecio de la vanguardia. Por eso en aquellos mismos días solían llover irónicas apreciaciones sobre quienes todavía seguían observando a ciegas tan socorrido recetario de mecánica versificatoria. Con seriedad fingida sostenía Forner: "¿La poesía acaso se reduce a otra cosa que a formar décimas, seguidillas, letras, octavas reales y romances de arte mayor y menor? Yo tengo en la uña al Rengifo y sé contar las sílabas y pies con tanta facilidad como la mismísima monja de Méjico ${ }^{2 * 3}$; y otro guasón de la misma calaña encomendaba la iniciación de todo poeta novel al mismo método infalible para aprender a «echar coplas de repente» - «Rengifo, hijo mío, Rengifo y siempre Rengifo»-, completándolo con detalles esenciales: "En primer lugar debes tener siempre en las manos las poesías del Maestro León Marchante, ingenio el más sublime en el equívoco, el qual, si logras imitar, puedes reírte de todos los poetas antiguos y modernos. ¡Con qué gracia maneja el equívoco! :Qué variedad de metros! ¡Qué ingenio para hacer reír aun con las cosas más sagradas como son los misterios de nuestra religión! » ${ }^{24}$.

Formados en tales convicciones y sin desconfiar lo más mínimo de su validez, nuestros poetas de sobremesa -actores y espectadores a un tiempomezclan con el mayor desembarazo lo divino y lo humano, buscando la agu-

20 Diario de Modrid, n. 38 y 39.7 y 8. II. 1975, pág. 150 y 153.

21 Manuel PARDO DE ANDRADE, Los atticulos del "Diario de Madrid" (1794-1800), T"un. dación Barrié de la Maza, La Coruña, 1989, pág. 35-45, 95-99, 131-137.

${ }^{22}$ Juan DIAZ RENGIFO, Arte poéticn española, Martí, Madrid, 1727, pág. 74.

27 Juan Pablo FORNER, "Exequias de la lengua castellana", en Poetus líricos del siglo XVIII, B.A.E., Madrírl, 1952, II, pág. 387.

24. Diario de Madrid, $11 . " 19$ 19.I.1795, pág. 73-74. 
deza a toda costa, seguros de la divertida complacencia que su ingenio es capaz de despertar en los presentes. Exhibiciones de este jaez ilustran a las mil maravillas la dificultad de conseguir un cambio en el gusto poético, que -como es sabido- era cosa que traía a mal traer a los reformadores de la época. Los convidados de Peñalosa, licenciados y predicadores, encarman con curiosa exactitud dictamen de Feijoo sobre el lastimoso estado de la poesía en la España de su tiempo y son retrato verídico de aquella infinita muchedumbre de los que hacían coplas sin ser poetas: No hay licenciado que, si quiere, no haga coplas», concluía desolado el benedictino ${ }^{25}$. Y, en efecto, llegado el caso todos los comensales -incluidos los «anticoplizantes»-se demuestran capaces de prodigarse en aquella irresistible mezcla de sonsonete deleitoso y erudición chirle, a un tiempo juego de salón y prenda de educación exquisita, encargada de no desmentir el origen de quienes la exhibían. Los Santa Cruz, Romay y Saboya que hacen el gasto en el certamen, miembros de familias ilustres por su origen y distinguidas por su posición social en el Reino de Galicia, revelan con su actitud el favor que lo más granado de la sociedad local ${ }^{2 i}$ seguía tributando a pautas culturales y expresivas ya en trance de caducar definitivamente $y$, aun con todo, percibidas como algo vivo y atractivo. Nuestros poetas de ocasión son, con toda probabilidad, segundones de esas familias ilustres, acogidos unos al claustro y otros a las parroquias rurales, separados del trato con sus iguales por el aislamiento de la celda o de la residencia aldeana y por ello mismo propensos a suscribir aquella confesión del Cura de Fruime: «Hago mis versotes por divertir esta soledad, donde la falta de comunicación con gente racional, el desticrro de mi patria, la total privación de recreo político, y aun de paseo delicioso, disculpa o justifica no poco este esparcimiento del ánimo...s ${ }^{27}$. Todos ellos, a la menor ocasión, volvian con gusto a los entretenimientos de sus años mozos, de éxito garantizado en toda reunión y más alrededor de una mesa, donde xel caballero secular, el canónigo, el cura, el religioso, el misionero [... solían echar], a manera de rosolio, su sorbito de Aganipe, acreditando así que éste es un licor que tomado con templanza entre comida a todos sienta bien... ${ }^{28}$.

25 Cfr. "Música de los templos", en Obras, Ibarra, Madrid, 1778, I, pág. 306.

26. Mediado el siplo era Decano de la Real Audiencia de Galicia Don Juan Luis Fernández de Saboya, vocal asinismo de la Academia de Agricultura inaugurada en La Coruña el 21 de enero de 1765: v. Galicia. Revista Universal de este Peino, II, 1862, pág. 375; por aquellos días Don José Ignacio Romay, Teniente Coronel de Milicias, era Señor de las casas de Illobre y Fiobre: ibid.

27 CERNADAS, Obras..., cit. III, pág. 24

2* Ibid. 
En perfecto pendant con aquellos malabarismos copleros que hacen las delicias de la concurrencia, también la prosa emperifollada con que el repentizador dedica sus esfuerzos al anfitrión -en un largo preámbulo- tiene más de gerundiana que de otra cosa y denota la vitalidad de un estilo, a pesar de los pesares. Se diría que el conocimiento expreso de la sátira de Isla no intimida lo más mínimo al frailecito poeta ni lo induce a limitar de manera alguna sus volatines retóricos. Al contrario, su alarde de un perfecto dominio de la técnica tradicional de exposición de textos sagrados, la descarga cerrada de autoridades bíblicas y latinajos traídos a cuento o por los pelos, su hiperbólico empeño en acumular lisonjas al anfitrión, transportan muy a lo vivo al lector de hoy al clima y a las estructuras mentales anteriores al neoclasicismo, reacios a desaparecer ante los embates de imperativos nuevos.

Ya se sabe que el aislamiento geográfico del Reino de Galicia favoreció siempre la pervivencia en él de estilos de vida y pensamiento no menos que de formas de expresión ya en vías de agotamiento por otras latitudes pero allí inusitadamente vigorosos. Este es el caso del favor disfrutado por un gusto literario ya declinante, "corrupción» heredada del pasado de la que abominó el Siglo llustrado por largo tiempo antes de lograr cancelar su prestigio. La sumisión al hechizo de lo barroco, difícil de sustituir, no arguye simplicidad ni rudeza de espíritu en quienes a destiempo continuaron adhiriéndose a sus connotaciones; si así fuera, si sólo la anticipación de lo futuro, es decír, la calidad de precursores, lograse categoría de valor auténtico, la crítica tendría por meta principal la de no dejar títere con cabeza. Como afortunadamente no es así, el historiador que no quiera renunciar a su nombre ha de saber valorar las huellas del pasado debidamente, sin desdeñar lo que no corresponde a lo que espera de ellas. Y según eso, las poesías de repente del fraile extremeño sin ser nada extraordinario desde el punto de vista literario -o quizá más bien por su futilidad- nos restituyen la imagen de una sociedad con sus ribetes intelectuales, que se nutre de ideas recibidas, avaladas por la tradición y que se divierte haciendo de ellas pasatiempo. Para el historiador este documento literario es un precioso instrumento con que acercarse a los gustos de la minoría rectora del Reino de Galicia. A ella pertenecía Cornide, cuya personalidad, formada según el gusto barroquizante que imperaba en sus años mozos, no permanece indiferente ante diversiones como la reflejada en este certamen. Harina de otro costal es que supiese disfrutar también con lecturas de carácter tan opuesto a los dislates de los copleros como los Night Thoughts de Young y las odas de Pardo de Andrade, igualmente conservados entre sus papeles. Pero esto es cuestión aparte, que requiere tratamiento adecuado y que a su tiempo lo recibirá. 
Certamen Poético *

Al asunto, que dirá este Papel;

que

Reverente, y obsequioso consagra, y ofrece

Al Señor Dn. Joseph García

Peñalosa

Alcalde Maior, que fue en las Ciudades

de

Truxillo, Soria, Toledo, y otras partes,

$\mathrm{y}$ al presente

Alcalde maior, Apoderado Gral. y Gover-

nador de estos estados de Monterrey etc

Fr. S.T.V.P. d. L.M.

d. $\mathrm{V}$.

Al Señor Governador Apoderado

General, y Alcalde maior de estos estados de

Monterrey

Dn. Joseph García Peñalosa

Carta dedicatoria.

Señor Paisano mi mui faborecedor, y dueño de mi maior estimon.

Todos los ríos, y arroiuelos caminen tan agradecidos como presurosos al Mar, como a centro, a quien debieron su origen, y principio: dice la verdad inlalible; omnia flumina intrant in mare... unde exeunt revertuntur. Por insondable Occeano de Nobleza, vizarria, y discreción aclama la publica voz, y sus relevantes prendas a V.M. de quien este poetico Certamen deribá su orijen. Pues que nació de haverme V.M. dado oportuma, y discretamte, un pie como suio. No fue esto darme de pie, ni aun de mano aunque saben V.M., y mis Sras, sienpre mis Sras. Paisanas dar muchos pasos, y ser ambidextros para honrrarme, y faborecerme tulta meritum.

Cinco Eclesiásticos, todos grandes en todo, excepto yo, que en todo soi pequeño, rodeahamos en cierto día la franca, para todos franca, mesa de V.M. a

* Se conservan la grafía y punuación del original.

AHRG, Papeles de Comidle, leg. 9-168. 
tiempo, que se me intimó la orden de decir algo en verso. Todos se bolvieron contra mi; y hasta mi Sra., siempre mi Sra, mi amabilissima Sra. Madre, hermana de V.M. se dio por sentida; juzgando desobediencia, lo que solo fue humilde reconocim ${ }^{\text {to }}$. de mi inutilidad; si ya no fue el estar mi Parnaso por el poco, o ningún uso, bravio, inculto, y lleno de malezas. Entonces, ya lo vio V.M., me escusé, que por la travesura de un mal parto Poetico, se me havia quedado lisiada la madre de mi celebro.

Por lo que aludiendo discretamente V.M. a esta mi dolencia, y al sentimto que mi Sra. Madre me mostraba, me dió el siguiente pie:

\section{está la madre sentida}

Y tomándome yo la mano entonces, (que no lo suelo hazer por más pies que me den) y en ella la pluma, luego que se levantó la mesa escribí dos décimas, no estando la musa para coplas. Ya las olió V.M., y puede bolverlas a leer, si gusta. Son las primeras que van puestas en este Certamen, y las que dieron motibo a los consabidos Anticoplizantes para insultarme del modo, que se verá en sus décimas, no dándoles yo, ni mis sencillas coplas ni [tachado] el menor motibo.

Conque del pie oportunamte. dado por V.M. nace como de un Océano de discreción el arroyuelo de este Certamen.

De sub cuius pede fons vivus emanat (es pensión de los Predicadores no poderse contener en embocar textos a cada paso, aunque sea a lo Gerundio) del pie de un cordero, dixo $\mathrm{Sn}$. Clemente, que vio nacer christalinas aguas. Representaban estas la gracia. Pues supuesto, que del pie, que V.M. dio, nacieron las corrientes de este certamen, haga V.M. la gracia de que corran christalinas de modo, que ningún Poeta Ganso las entarbie.

Buelvome pues al principio. Bien las corrientes de mi discurso se dirigen apre-

2 vto. suradas, quanto agradecidas con la dulce fuerza de la voluntad más fina, acia el insondable christalino Piélago de vizarría, nobleza, y discreción de V.M. de donde tubieron su principio: unde exeunt revertuntur de sub cuius pede fons etc.

Pero siendo V.M. Peña dos veces por Peña Losa, jcómo podrá ser Mar, cuios senos nazcan raudales, y de cuios pies se originen fuentes? Mas ¿quién no vio desatarse algunas Peñas en christalinas aguas? Yo por lo menos algunas vezes las vi sin milagro.

Cierto es, que para dar agua una Peña agua en el desierto, llamado Sin, en el sitio de Cadés, fue antes herida dos veces con la vara de Moisés: Moisés percutiens virga bis petram egreses sunt aquęlargissimę Pero notaron algunos In- 
terpretes, (y cualquiera lo puede ver en el capitulo 20 del libro de los Numeros) 3 que Dios no le mandó herir a la Losa con la vara, aunque se la mandó llevar en la mano (que no es todo uno ordenar Dios, que se lleve vara en la mano para la autoridad, que el que se lastime, ni a las piedras con ella) el Señor solo le dixo, que hablase a la Peña, que ella solo con esta diligencia daría agua, y aun aguas: Loquimini ad petram, et illa dabit aquas. Solamte, con hablar a la Los $a$, sin herirla (porque hai palabras, que si no hieren, matan aun al hombre más peñasco) daría unas aguas más dulces, que una miel, como las dio. Aunque agraviada de las heridas pudo responder con amarguras, mas no pudo, que aquella Losa era símbolo de la paciencia del mejor, y más constante Job, nuestro Señor JesuXpto, que vertió lagrimas compasibas por sus enemigos, que regó con los preciosos raudales de su sangre la maldita tierra, que le perseguía, que brotó caudalosos ríos de perdones por los mismos, que le escarnecían, blasfemaban, arrastraban, azotaban, y herían con espinas, clavos, y lanzadas: percutiens bis petram egrese sunt aque largissime.. Petru autem erat Xptus. Todo del citado capítulo de los Números del Real Profeta David, y del Apostol de las Gentes.

De esta casta de Peñas es V.M. (nadie se escandalice, pues de la cantera de Xpto somos los Xpistianos labradas piedras, de donde resulta la fábrica de la Sta. Iglesia. Atendite ad petram unde excisi estis, de Isaias al capo 51. Y SM. Pablo: fratres: estis superedificati super fundamentum Apostolorum, ipso sumo angulari lapide Xpidesu. (Ad ephes. 2). Y Sn. Pedro (in Epist. 1" cap. 2) Ad quem accedentes lapidem vivum... et vos ipsi lapides vivi superedificamini.) De esta casta de Peñas es V.M., decía que sabe dar copiosos raudales de constancia, de juicio, prudencia, y discreción. En unas Losas se gravaron por orden de Ds. las leies sagradas, para que no se perdiesen, ni borrasen, y para su firmeza. Y si las sagradas leies canonicas, y civiles se perdie/ran, se encontrarian mui fimem tee. gravadas en las Peña y Losa de V.M. como lo gritan la voz comun, y las ciudades principales de España, donde fue, no tanto Juez, quanto Padre, Nunca necesitó, como Moisés, de herír con la vara, para acreditar la más [entre líneas] justificada conducta en todo genero de materias. Sabiendo convertir la vara, que castiga por lo que expresa de rigor, y justicia, en báculo pastoral, que sustenta, por lo que simboliza de celo pastoral.

De esta manera copió V.M. en su judicatura las nobilisimas, y prudentes acciones del mejor dechado de ministros, de aquel grande Nombre, del nombre y aun sobrenombre de V.M. [tachado: de aquel, digo, Joseph, que se llamaba], de aquel primer Ministro del Rei faraon, de aquel digo, que se llamaba Joseph, en creciente, por lo que hasta en el nombre dice de aumento, y Peña, o Losa, según interpretó el Gran Patriarca Jacob su Sto. Padre en la bendición, que le dio al morir (Genesis cap. 49); Filius acrescens Joseph, filius acrescend... inde 
Pastor egresus est, Lapis Ysrael... Joseph id est aumentum: dice la común interpretación.

Estas tan abundantes, y dulces aguas de vizarría, prudencia, y discrecion sabe dar la Peña Losa de V.M. sin herir y sin ser herida; mui naturalmente y quando mas, como la Peña del desierto Sin, y Cadés por la poca costa de abrir los labios los que las quieran beber: loquimini ad Petram, et illa dabit aquas.

Por esso es de extrañar, que bebiendo algunos, del pie, o al pie de esta Pe$\tilde{n} a, o$ Losa desatada en aguas tan dulces, sean éstas en amargas hieles convertidas. Díganlo los consabidos Anticoplizantes. Al pie de esta dulce fuente de la Peña Losa de V.M. han bebido; pero se les avinagró de tal modo en sus estómagos lo que bebieron, que no fue mucho, bomitasen dicterios, tan amargos.

4 Digo que era esto de extrañar, pero no mucho, pues ¿̨quien no sabe, que de una misma flor bella, y fragante sacan la Araña veneno, y miel la Abeja?

Por esso un yngenio pintó una flor hermosa, y sobre ella, chupando a un mismo tiempo su dulce jugo una Abeja, y una Araña, y este epigraphe por mote: quam vis homogeneum, hinc mel et inde venenum. Conque la culpa de bolverse amargas las aguas destiladas del pie de la Peña Losa de V.M. liquidado en fuente, no es de la peña, ni de las aguas; es sí de lo avinagrado de sus indigestos estomagos. Aguas de contradicción, dice el divino Oraculo, que se llamaron las que dio la Peña milagrosa del desierto, simbolo, como diximos con Sn Pablo, de nuestro Señor JesuXpto. Pero ni la Peña ni sus aguas fueron el motibo de llamarse assí; fuéronlo empero, los Israelitas, que mal estomagados, como nuestros Anticoplizantes, convertían en amargas hieles las ambrosias mas dulces, con su espíritu de contradicción. El oráculo: Hęc est aqua contradictionis, ubi iurgati sunt filii Israel; en el cap. 20 citado de los Números, y en 17 del Exodo: Vocavit nomen loci illus (el sitio donde la Peña dio agua) tentatio propter iurgium filiorum Israel.

Pero ¿qué se me dará a mi de sus amarguras, ni de que sin darles V.M., ni yo el pie se aian tomado las mano para insultarme los Sres. Licenciados Anticoplizantes? jIgnoraban, que V.M., y esas mis Sras. Paisanas eran mi Patrocinio, y que con tan firmes, y bien labradas Peñas Losas, tenía yo una incontras4 vto. table torre de refugio, un fuerte, por antonomasia fuerte, en esse Monterei (ahora) de los Montes todos, entrando al Parnaso con sus Ninphas, y todo?

Oigan los Gerundios el más literal texto: statuit super Petram pedes meos, et direxit gresus meos; decía cantando el Profeta Rei burlándose de sus enemigos, y yo mofándome de los míos lo digo rezándolo: Los pies todos de estas mis décimas, acompañados del más intenso afecto, los puse, y pongo debaxo de la 
Protección del Señor Peña Losa: statuit super petram pedes meos, y de esta suerte por más, que los torcidos Anticoplizantes me roan mis pies o mis zancajos: ipsi calcaneum meum observabunt, queriendo, que mis pisadas sean como las suias torcidas no les debo temcr. Et direxit gresus meos enderezaré mis pasos; mejor diré: no daré paso que no sea acia V.M. (esto se entiende de texas abaxo) que es mi Peña, mi Losa, mi fortaleza, o mi Patrocinio, que todo es uno, dixo el Profeta coronado, hablando con Dios, en el Capítulo 22 del segundo de los Reies: Dominus Petra mea, el robur.

Y porque esto no se quede assí en los términos literales, pondré aquí unas especies, que me ministró el grande Lorino sobre estos citados textos. El Psalmo trahido en el citado capítulo 22 del segundo de los Reies: Dominus Petra 5 mea etc. es en la sustancia, dicen los Interpretes, el mismo que entre los Psalmos empieza: Diligam te Domine fortitudo mea y es el 17: el que cantó el Profeta, quando le libró el Señor de sus enemigos, especialmente de Saúl; y dice, que Dios, es su Peña, su refugio, su real, su fuerte, su castillo etc. Dominus Petra mea, et robur; Dominus firmamentum meum, et refugium meum, aludiendo, dice el citado Lorino (in Psalm. XVII, ver. 3) al Lance, en que viéndose el Profeta apurado de sus émulos, se refugió, a una Peña, que se hallaba en un sitio llamado Maon, en lo alto de um monte intitulado Ziph, lugar mui fuerte, y mui seguro, como si dixeramos una Plaza de Armas como Monterey [añadido entre renglones:] el Psalmo: Dominus Petra mea etc, y Lorino: Alludit forsam David ad firmissima loca, tutissinaque Montis, in solitudinis Ziph, et ad Petram in deserto Maon, ad que David Saulem vitans confugerat. Y como aquellos sitios de la Peña de Maón, y del Monte Ziph fueron refugio, y protección para David, por tanto atribuiendo el $\mathrm{St}^{\circ}$ Profeta a Dios el haverle deparado aquel fuerte Peñasco para su seguridad, da al Señor las gracias llamándole su Monte Ziph, su Peña Maon, su refugio, su patrocinio, su fuerte, y su plaza de armas: Dominus Petha mea, et robur... Dominus firmamentum meum, et refum [sic] meum etc. Otra vez Lorino aquí: Significat Profeta sibi Deum in fuga Arcem; in periculis liberatorem; in pugnando adiutorem; in propulsando Chpeum in feriendo adversarios cornu; denique defensorem, et muneratorem, dicit fuise. Sobre todo en la lengua Hebrea todo es uno: Peña, Piedra, Castillo, y fortaleza: Significat Hebrea dictio (aquí pone Lorino la dicción en [tachado: hebreo] caracter hebreo) petram, saxum, rupem, arcem etiam, et munitionen.

No Saúl, sino Saúles son los que con dicterios me insultan con menos motibos, que los que Saúl tubo para perseguir a David. Ni es mucho fuesen entre sí émulos, disputándose entre los dos no menos que una Corona. Pero entre los Saúles Anticoplizantes, y mi persona no hubo causa para el menor disturbio; de mi parte digo, si no es que fuese la emulación de cierto parentesco. 
Pero para que mejor se vea la fuerza de este simil, refiérese en el capítulo diez del libro primero de los Reies, que haviendo el Profeta Samuel ungido por Rei a Saúl le profetizó, y se verificó la Profecía, que al baxar de un Monte y entrar en un Valle, cerca de un fuerte, encontraría con una caterva de Músicos, danzantes, y Profetas, o Poetas (que todo lo significa la voz vates.) [tachadura] gente toda de buen humor, de los nuestros, de nuestros Anticoplizantes, digo: post hęc veniens in collem... ubi est statio... et obium habebis gregem Profetarum (esto de decir rebaño de Profetas, suena a gente perdida, por lo que suena de ganado) descendentium de excelso, et ante eos Psalterium, et timpanum, et tibiam, et cytaram, de todo había en la Procesión; que no iría mui ordenada componiéndose de Poetas, y Músicos, de Pitos, flautas, y Atabales.

Pero vamos al caso; encontróse Saúl quando venía en busca de sus Pollinas (no sabemos si era arriero) con esta tan juiciosa caterva, y de repente [sobre el renglón:] se entró entre los Músicos, y Poetas, o adivinos; tomó su instrum to [tachadura] (alguna Zanfona, quitándosela a algún ciego) y después, que [tachadura] tocó un sonsonete, o algún pasa calle (que pudo ser, siendo dentro de la ciudad: cumque ingresus fueris urbem) tambien dixo su relación; coplizó, como uno de tantos. Los que veían a Saúl entre los Poetas, y Músicos, metido a Músico, y Poeta, y sabían que sólo solía entenderse con sus Pollinas, se pasmaban, y decían: Quenam res accidit filio eis? num, et Saul inter Profetas? como si dixeran: Un hijo de tio Cid el Arriero (es aquí el ordinario de Salamca.) que no supo andar, ni hablar, sino entre sus Bestias, ¿ahora entre los Poetas, y Músicos? Tal fue la admiración de todos; y la repetición de sus pasmarotas, que quedó por proverbio, o adagio: Propterea versum est in Proverbium: num Saul inter Profetas.

No quiero, ni debo querer, que [tachadura] el símil venga como se suele decir a quatro pies. Los Anticoplizantes Saúles, mis émulos, son de notoria calidad, ylustres en nacim to. y crianza. Todo el mundo sabe, que no vienen de casta de Arrieros. Son assimismo Leídos lo que se necesita para el grande empleo, que dignamte. llenan y aun para más. Pero en materia de Poesía (facultad, que ni quita, ni pone a los hombres grandes, o pequeños, aunque suele el vulgo graduar a sus Profesores de poco seso, quando [tachadura] es necesario mucho para facultad tan intelectiva) Digo, pues, que en materia de Poesía me parecen mis Anticoplizantes unos Saúles [sobre el renglón:] unos Arrieros en las pernas. y 6 vto. assi quando leí sus Décimas exclamé: nun et Saul inter Profetas? tengo la fortuna, que no fui solo en este pensamiento, y que más de quatro piensan, no fueron las tales Décimas composición suia.

Mas sea lo que fuere; David al verse perseguido de Saúl, no obstante ser tan 
valiente, que se burlava su valor de los Príncipes de las fieras, y de los hombres más gigantes, se acogió a lo alto de un Monte, donde halló una altísima Peña, o Losa que le sirvió de refugio, y de Plaza de Armas: Petra mea, et robur firmamentum meum et refugium meum. Assí yo aunque puedo medir mui bien [solire el renglón] sin ser jactancia la espada de mi Musa con mis Anticoplizantes Sales, no obstante me acojo, como a sagrado a esse Monte=rei, como dixe, de todos los Montes, (a lo menos en las presentes circunstans.) entrando al Parnaso con sus nueve bellíssimas Ninphas; Monte, donde residen tan firmíssimas, y tan encumbradas Peñas Losas, que son, y han de ser para mi, como la Peña de David, en la fuga fortilicada trinchera: in fuga Arcem. I ibertadores en los peligros, in periculis liberatorem, defensores en las Palestras: in Pugnando adiutorem, en los botes de Lanza, espada, y las demas armas ofensibas, impenetrable Armés, o escudo: in propulsando clypeum. Un Batallon formidable en perseguir, herir, y matar mis enemigos: in feriendo Adversarios, cornu y en fin essos, y essas Peñas losas, residentes, como la Peña de David, en ese encumbrado, y fortificado Monterey, son, y han de ser, annque sin mérito mío, mis perpetuos defensores, y mis faborecedores perpetuos, a pesar de la emulación toda, y de los Sres. Anticoplizantes míos: denique defensorem, ac muneratorem.

Luego puedo gloriarme con el coronado Profeta y decir: in Petra exaltavit me. Mis honrras, mis glorias, mis creces, y aumentos los hallé [tachadura] en una Peñalosa. Peña donde salen raudales copiosíssimos de nobleza, de urbanidad, y de vizarriad [sic] de únimo. Lase [entre líneas] de donde se originati ríos caudalosos de ciencia, Prudencia, y discreción, a la manera, que las Peñas, o Losas del desierto dieron larguísimas, christalinas, y dulces aguas: de petra egreşsunt aquęlargissimę(nume. cap. 22) eduxit rivos de Petra (Deuteron. cap. 8) in Petris vivos excidit (Job. cap. 28).

In Petra exaltavit me, esta Peña, que dice David, fue su exaltación, es la misma dicen los Ynterpretes sagrados, citados en Lorino, que la Peña de aquel Monte Ziph, o Maon, donde se refugió el Profeta huiendo de Saúl; y esta misna la expresa en otro Psalmo, que ya cité: statuit super Petran pedes meos. Y aquí luego Lorino: exaltatio in Petra denotat constitutionem in loco firmo, ac tuto, sicut et siquis constituartur super excelsa (Lorin, in Psalm, XXXIX, ver. 3). De esta suerte lo mismo es poner yo los pies de las Décimas de este certamen a los del Señor Peñalosa, que ser exaltados, siendo, como lo son, dirigidos a esse excelso Monterrey, a essa fortaleza, y en esto están mis creces, mis aumentos, mi tutela, y mi defensa.

Lo que Sn Bernardo dice de una Peña a cierto asunto, en el sermon 61 de los Cantares, digo yo de V.M. ¿Que propriedad apreciable no se halla en el Se- 
7 vto. ñor Peñalosa? Todos, especialmente sus faborecidos hallamos aumentos, seguridades, y firmezas. El sancto: Quid non boni in Petra? in Petra securus, in Petra firmiter sto, securus ab hoste fortis a casu, et hoc quoniam exaltatus.

Pero ¿qué? ¿No pisé ya las líneas de lo sucinto, como lo requería un papel de tan poco momento, como esse, que remito a V.M.? Quiso llevarme la voluntad, donde llegar era imposible. Sé, que sabe V.M., no se valora la ofrenda por lo que es, sino por el ánimo con que se executa. El mío, y la fineza de mi afecto ya V.M. lo tiene bien tanteado; pues no ignora, que correspondo a las honrras, provechos, y Patrocinios, que no busco en esta Dedicatoria, porque los tenga ya mui en mi posesión, hallado, desde el punto, que logré la dicha sin igual de rotularme de V.M., y de esas mis Sras., siempre mis Sras. (que Dios gue. $\left.m^{s} a^{s}\right)$.

Servidor cappn ${ }^{n}$ y Paisano el menor aunque el mas obligdo. Q.S.M.B. fr. S.T.V. En 6 de Henero de este año de 1759.

$$
\mathrm{Ss} \cdot \mathrm{Vn} \text {. }
$$

Dícese su motibo, y causa.

Una cierta Sra., de sublimes circunstancias, fue servida de adoptar por hijo a fr. N. (por los motibos, que el referirlos no es del presente asunto) teniéndolo el tal por superior fortuna. En ocasión de estar éste convidado por unos días, por ciertos Sres., hermanos de dicha Sra., un día concurrieron convidados a comer dos Sres. Abbades de los de primera clase en todas circunstancias, y otros dos religiosos condecorados, empeñáronse las Sras, y circunstantes todos en que el dicho fr. N. havia de decir algo en verso, informados, de que adolecía de este achaque, llamado furor, o rabia Poética. Escusóse el referido quanto pudo, significando su inutilidad, y yo creo fue que estaría su pensamiento embobado, como dicen, con la ganancia, teniendo a la vista a sus Sres. tíos, a las primas sus Sras. y sobre todo a su Sra. Madre. O sería, que la Magdalena no estaría para tafetanes, como se suele decir. Fuese uno, o fuese otro, que esso el solo fr. N. lo sabe; el caso fue, que sintieron todos su terquedad, y especialmte. su Sra. Madre se dio por más sentida, y con razón; por lo que, y por haver dicho el referido fr.

8 vto. N. que la Madre de su celebro havía quedado sentida del último mal parto poético, aludiendo a estos sentimientos de una, y otra Madre, dio oportno, discreto su Señor tío, el pie siguiente. 
Levantóse a la sazón la mesa, y el referido fr. N. aunque realmte, no estaba para coplas, fundó sobre el mismo pie la dificultad, que tenían los conceptos de su lisiado entendimito. en salir a la luz, o en ser partos.

Y por quanto hai algumos de tan débil estomago, o tan indigestos, que ni el más digerido pisto pueden triturar su inútil Quilo, o sus disolventes enfermos áccidos, voi a presuponer dos advertencias presupuestas una en la Philosophia, y en la Anatomía la otra: Aquélla enseña, sin disputarlo que el entendimiento se divide como en dos, diversos cargos, que exerce. Como agente depura la Materia de la especie, que se concibe, házela espiritual; y la imprime, o engendra en el mismo entendim to. como pasible, el que haze vezes de Madre; y assi con propriedad [tachadura] hai en el entendinto generación, conceptos, y partos. Por esso dicen bien los theólogos, que el verbo divino, la Segunda persona de la SSma. Trinidad es con propiedad parto etemo del eterno entendto, del Padre. Y tambien se dice mui bien, que un libro es parto del entendimiento de su Autor.

La otra advertencia presupuesta en la Anatomía es que en lo anterior del celebro, oficina de las potencias del alma, hai una membrana temuissima lla9 mada Pin Mater, cuio uso es embolver el celebro hasta sus más profundos giros, y sustentar los vasos, que entran, y salen del. Assí lo dicen los Anatómicos, y entre ellos Martín Martímez en su Anatomía completa del celebo fol. 383. Conque corn razón esta membrana sc llama Madre, y piadosa, supuesto, que tan piadosamte, y con tanto cuidado sustenta a todo el celebro, a sus fibras músculos, y vasos, instrumentos príncipes, donde principalmete. residen las potencias del Alma. 'l'an sentida es esta Pia Mater, que lisiada, si no quita la vida, a lo menos haze que las polencias, y sentidos estén como embargados. Y assí dicen los Anatómicos, que de mui poco se ofende por ser sensibilissima.

Supuestas estas noticias, que para los más serán mui viejas, o sabidas, y supuestos los expresados sentimtos. de la pia mater del celebro del referido fr. N. y assimismo los de su Sra. Madre (que por lo cariñosa, y sentidissima puede competir, y sobrepuxar a la misma membrana Pia Mater) el dicho adoptado hijo dixo assi:

\section{Décima $1 .^{0}$}

Aunque fácil siempre fue, y gustoso el concebir pero esto de parir siempre tubo un no sé qué. En mi Madre ya engendré 
[renglón tachado]

una especie mui cumplida;

no la pude dar salida,

de un mal parto, en que me vi;

¿cómo pues pariré si

está la Madre sentida?

\section{$2 .^{a}$}

Y si aun no estando lisiada

la Madre se pare mal,

a puro dolor fatal;

¿qué será estando maleada?

Mi Madre estubo preñada, y felizmente parida.

Mas ya la tengo torcida;

y viéndome assí apurado

con este tan mal preñado

está la Madre sentida.

9 vto. Estas Décimas assi escritas se leieron delante de todos, y al acabarse de leer, un Anciano venerable por su Profesión campeón de la mas escogida Compañía, veterano en las Palestras literarias, theologicas, escolásticas, y místicas, mui hijo de Minerva, y a Belona afecto; y en su conciencia invencible, y erronea mui veterano en las campañas de Marte, y de Apolo (Dios de las Musas) siendo tan visoño en la Poesía, y en el arte militar, que ni puso los pies en el Parnaso, ni vio la cara del Dios Marte de puro cobarde; este pues docto, y venerable Anciano, dixo, que diría algo a las referidas décimas con los mismos pies, si fueran más limpios.

Permítaseme, como Parénthesis escribir aquí dos décimas, que el consabido Fr. N. dixo contra la vana presunción poética de este citado Venerable de repente.

\section{Décima $1 .^{\mathrm{a}}$}
El que de todos es cruz* piensa, que va viento en popa
su Musa, que es nave sopa
rota sin vela, y $\sin$ luz.
Suele dar tal qual chapuz
y en él ahoga el cuitado;

*se llama el sujeto Sta. Cruz 
como es viejo, y tan pesado

qual cruz, no es mucho se vaia

a fondo: denle pues baia

por coplizante azoilado.

$2{ }^{a}$

A mi ya ven que me toca

desengañar a ese Padre,

aunque lo muerda, y le ladre,

y aunque es ya viejo con moca.

Es gentil hombre de boca

por lo que habla sin zozobra;

mas en cierta maniobra,

que se dice coplizar,

no lo ha llegado a catar,

ni de palabra, ni obra.

Cierro el Parénthesis; y aumque, como iba diciendo, se escusó nuestro Venerable Anciano, con que no decía algo a las referidas décimas, con los mismos pies, porque eran poco limpios, no faltó un descarado, que sacó la cara. Pidió dhos, pies agenos, como quien no podía dar un paso con los proprios de tortuga: corrió con ellos, aunque no tanto, que no pudiera qualquier galápago alcanzarlo. En siete, u ocho, o más días llevado con los dhos, pies agenos, y como cojo en muletas nuevas, y por domar, que brincarían por las picas de Flandes, anduvo el Pobrete (o andubieron pues andubo en compañia) la corta jornada de quarenta pies, no cabales, en quatro décimas incluidos. Oigan las dos primeras con el frontis, que las pussieron:

Décimas a lo divino en respuestas de unas mui a lo humano con los mismos consonantes:

$$
\text { 1. }
$$

Escogida muger — fue

la que debió — concebir,

y siendo virgen — parir

al deseado; mas — ¿qué?

Si ab eterno yo — engendré

hermosura tan —- cumplida

tardaba ya la — salida 
y cuando en tiempo me- vi

dixo el Padre, nazca __ sí,

no esté la Madre — sentida

\section{$2{ }^{\mathrm{a}}$}

Parió, y sin ser ___ lisiada

nos libró de todo _ mal;

pues estando tan _ fatal

la tierra, y $\tan$ - maleada

que de pecados — preñada

aun despues de estar — parida

para lo bueno — torcida

lo malo todo — apurado

se libró con el - preñado

de una muerte — con-sentida.

Estas son las décimas, que dicen sus Auctores, son a lo divino acaso porque serán divinamte. compuestas. Ellos lo pensarán, pero lo cierto es, que en ellas se encuentran algunos alifafes. Para entender de una, y otra Décima la Derrota necesitase de muchos remedios; de modo, que si todas sus roturas se hu-

10 vto. bieran de remendar, fueran como capa de Pobre, que no se conoce de que fue la primera tela. Debemos mirar más a lo que quieren decir, que a lo que dicen. Dirán, que como son de pies forzados, no se puede explicar lo que se quiere; que en esso está el Arte. Véanse las mías todas, especialm te. las místicas con los mismos pies forzados, y se notará, que aunque no lleven sublimes conceptos a lo menos tienen buenos romanzes inteligibles.

En los primeros quatro versos de la primera decima hablan, como un Profeta escogida muger fue etc. Despues introducen de repente al eterno Padre hablando, pero sin advertirlo. No sabemos quién allí habla, si no se adivina. Tampoco sabemos los que no somos theologos, quien es aquella hermosura, tan cumplida que engendrada fue ab eterno? La decima no explica, si es el deseado, o la escogida mujer; pudiendo ser ésta, pues eternamte. estuvo ideada en la menta divina. Dirán, que el deseado, el verbo eterno, fue sólo con propriedad el engendrado [sobre el renglón:] en la eternidad, por el eterno Padre, y no la Virgen; que ésta como obra de las que corresponden ad extra, es hechura de todas tres divinas personas igualmte. y no fue con propriedad engendrada [sobre el renglón:] por Dios sino criada, o hecha por todas tres [id.:] personas. Esso dicen los Sres. Theólogos, pero los que no lo somos, necesitamos, que nos lo expliquen en términos distintos, de los que las Décimas lo explican. Y sobre aque- 
llo de decir el eterno Padre: y quando en tiempo me vi, me dixo un tehologo, que era muy mala locución, que Dios no se ve, ni se puede ver en tiempo. Dios sólo se ve en si mismo, y en su eternidad. Querrán decir, que cuando se llegó el tiempo predefinido por el Padre eterno de nасеr el verbo, se dio éste a ver al mundo, pero esto no es verse Dios en tiempo, sino ver los hombres en tal tiempo a Dios humanado, que es mui distinto verse $D^{5}$, en tiempo, del ver nosotros en tiempo a Dios.

11 Y aquella última clausula de la segunda Décima: lo malo todo se libró con el preñudo de una muerte consentida, tampoco lo entendemos bien los romos. Paréccme mala alegoría, y locución mui metaphorica decir que nos libro del pecado el preñalo de la muerte de Xpto. Si dicen que el preñado significa a $X_{\mathrm{p}}$ to. en el vientre de la Virgen, y que este nos libró del mal de la culpa, bien dicho; pero el Señor en ese estado, no es preñado de muerte sino de vida, y sin rigor el Señor en el sagrado utero de la Virgen, ni es preñado de vida, ni de muerte: la virgen es la que estuvo preñada, engendrando, y traiendo en su Ssmo. vientre al Redtor. que es la vida eterna. Dexo otras muchas réplicas, que pudiera poner a una, y otra Décima.

Y voy a poner las mías a lo místico, por no decir, como los Anticoplizantes, a lo divino. Suplico a los discretos, se sirvan de cotexar con justicia las suias con las mías; advirticndo antes dos cosas. La primera, que sus cuatro Décimas fueron hechas con aiuda de vecinos, con asistencia (moral a lo menos) de comadrona, y médicos. Las mías, como sabe todo el mundo, yo a mis solas me las concibo, y yo me las paro. Lo segundo, que advierto es, que sus Mercedes, los Sres. Anticoplizantes, emplearon (como lo haré visible) más de ocho días en componerlas. Y yo como lo haré bueno, no empleé dos días enteros, en la composición original de todo este Pastel, entrando Poesías y Prosas, y hasta la Dedicatoria, que fue la que más me costó.

Síguense primero dos décimas, que son con los mismos pies, y aun con los mismos conceptos de las de los dichos Sres. Vienen a ser éstas dos primeras, como remiendos de las suias. Las otras dos siguientes, aunque van con los mismos pies, llevan otros conceptos.

\section{Décima $1 .^{\mathrm{B}}$}

El entendimiento — fue.

de Dios el que - concebir 
supo al verbo, y aun — parir

mirándose en sí, mas — ¿qué?

(dice Dios) al que - engendré

como mi imagen — cumplida,

déle una virgen — salida

pues que tan digna la - - vi,

y ella dixo fiat - sí.

sin ser mi Madre — sentida.

\section{$2 .^{a}$}

La Virginidad — lisiada

no fue: y de todo — mal

libre fue, aunque el — fatal

Dragón la quiso — maleada,

y aunque por él tan — preñada

era nuestra alma, y — parida

de culpas, y así — torcida,

todo el mal se vio — apurado

con un bendito — preñado

de una Virgen mui — sentida.

\section{$3 .^{a}$}

I Ieva la primera — fue,

que allá supo — concebir

en su alma, y aun — parir

un herror, un no sé - qué.

Debió decir: —— engendré

la iniquidad más — cumplida;

dila mui mala — salida

quando en presencia me — vi

de Dios agraviado; o - si

fueras Alma más — sentida.

$$
4 .^{a}
$$

La Alma quedó — lisiada

enferma del peor — mal,

que es la culpa mal — fatal,

que a toda dexa - maleada. 


Assi de horrores - preñada
es, y de monstruos — parida;
sólo para el bien — torcida
fue su conato - apurado;
que es un infierno el — preñado,
si la culpa es con — sentida.

Allá van (dicen ahora los Sres. Anticoplizantes en la carta, que me escriben) Allá van Ri,mo. Padre otras, que salieron currente calamo (si se han ido en siguidillas, como se fueron en Décimas, les creo, que se irían corridos, y corriendo, y en tal caso mano currente) tal sopla la Musa (soplen en hora buena) que esta noche las apuesta a todo el Parnaso (no percibo porque tanto se fatigan en decirnos en estas, y otras cláusulas (que después se citarán) que sus coplas las hazen de noche a obscuras, y sin candil. Ellos así lo dicen, y pues lo dicen assí, y assi estudiado lo tendrán, sabemos que al uno de los dos le faltan algunas luces, es defecto que sale a la cara, y no lo puede ocultar por mas dili12 gencias que haze con uno de los vientos del sombrero, y los dos deben de ser Yuge nios murciélagos, o lechuzas pues para bolar currente calomo andan a obscuras, y aguardan a la noche para dar sus buelos; ni querer ser encandilados por las luces de sus candiles mugrientos). No es mucho (prosiguen) que, piso buena hierva (aquí habla uno solo de los dos, y así no sabemos, aunque se trasluze, qual de los dos es pisaverde) decimos assi con los mismos consonantes (aquí dicen, que los dos hablan; hablen mui en hora buena).

\section{Décima 1. ${ }^{a}$}

Mui grande locura — fue el querer tu concebir, quando sabes, que el -- parir es de solo aquellas — que; No digas, no - engendré; pues aun tu intención — cumplida no hallara buena — salida; porque quando allí te — vi dixe; por aqueste — sí está la Madre — sentida.

2.

Tu mollera es la — lisiada;

Dios nos libre de tal — mal; 
tu concepto es bien - fatal;

y tu musa la — maleada;

estubo tan mal — preñada:

peor estubo de - parida;

salio la prole — torcida;

y al verte $\tan$ - apurada,

no es mucho que en tu - preñado

esté la madre - sentida.

\section{Diximos}

Assí finalizaron los Sres. Anticoplizantes sus dos tultimas: y si algún voto tengo, le doi a su favor, fallando, que a to humano dicen divinamte. y mui humanamente quando quieren hablar a lo divino. Digo otra vez que estas últimas décimas me parecen bien compuestas pero añado, que no vienen al caso. Por el contexto veridico de lo referido ven los discretos, que quando yo con nadie me metia, sino con mi camisa, con mis calzones, con mis conceptos, digo, y con mis 12 vto. Partos, confesando ingenuam te. sus defectos, como mios, se me vienen a provocar el Ingenio y Medio (que sus Mercedes se hazen la Merced de llamar, como después veremos, y el Medio Ingenio que reparto yo entre todos, haciendoles Merced). Por esso dixe, y buelvo a decir, que sus últimas décimas están buenas, pero me mantengo en que no vienen al caso; y arguio ad hominem.

En cierta ocasión en que concurrimos los Sres. Ingenio y Medio, y mi Persona (que ni es ingenio, ni medio) a una mui grande función, me mandó un Superior [entrc líneas] mui mio, (aunque de Religión distincta) que dixera una décima, dando en rostro con una falta [entre líneas:] disconforme que en sus rostros tenían uniformemente, uno de los dos Ingenio, y medio, y otro medio Ingenio también, por tentado de la rabia poética. Me resistí lo posible, pero apurado dixe assí:

Décima

Un Quixote excomunal alla mora entre los muertos, que desfacía los tuertos con un valor sin igual.

¡O! ¡quien otro como el tal Quixote resucitara! entonces le suplicara que a un Abbad, (ojo avizor) $\mathrm{y}$ al secretario maior a los enderezara 
Púsose el consabido rostrituerto, como si antes no lo estubiese al oir esta décima, y dixo brebe y compendiosamte. en prosa: buena décima pero no viene al caso; y esto mismo digo de las que ellos me cambian; pues en ellas sin ve13 nir al caso me insultan.

Ya se oieron los dicterios, que entre ceja y ceja me ensarta, con tan poco miramiento, como quien en su cara no tiene ojos, para ver, que no es razón hazer mal a quien mal no haze. Y aquello de llamar torcidos, o tuertos, las proles y partos de mi entendimiento en aquel verso de uma de sus décimas: Salió la prole torcida, es con toda propiedad ver la paxa en el ojo ajeno, y no ver la viga de Lagar en el suio. Pues Señor mio adonde las dan las toman, alla van essas chinas, aunque como van torcidas no tirarán en derechura a ofender. Mis armas, como nobles, no tanto ofenden, quanto a defenderme se dirigen.

Sirvan de medio Prólogo esse par de Decimillas, que llevan pies libres, o sueltos para que assí corran más, a manera de Siguidillas:

\section{Décima $1{ }^{a}$}

Mucho me abate un Abbate; ¡hábate pues si te cojol que te cegaré cierto ojo, quedándote a obscuras; tate, que luego saldrá al combate, y palo de ciego habrá; y mas que enseñado está a darlos a troche, y moche; será un Dn. Diego de noche, que aun assí se asombrará.

\section{$2 .^{\mathrm{B}}$}

¿Un extremeño alentado tan ajado de un gallego? aun de mi mismo reniego en verme assí provocado. Al primer revés cortado e] Gallego se verá; ya sé, que me alegará, como lo hizo otras veces servizios reales; mas hezes por servicios probará. 
Y por cuanto el Señor acompañado uno, de los dos (que se llaman Ingenio, y medio) no fue, según tengo noticia, el más corto por los dicterios, y esso que 13 vto. es Beato de Profesión, y mátalas callando, no será razón, que se vaia sin su sacudidura. A lo menos no puede negar, que firmó junto con el otro cavall ${ }^{\circ}$ los dicterios, dando fin con un diximos como quien se ratifica en lo dicho, que es duplicado maldecir. Y también sé, que ocurrió, no solo para embiarme a mí las dhas décimas, y las prosas, que aquí se refieren, sino que, de acuerdo de los dos se embiaron a cierta comunidad docta y religiosa para que sus individuos todos en Compañía viesen sus númenes a costa mía. Conque no deben de quexarse si mas de quatro acertasen a ver la merecida respuesta. Si dicen, que lo hicieron en tono de fiesta, yo no canto en otro tono en este papel.

\section{Décima 1.}

Juzgarán, que me he olvidado del Beato narigón, el que en aquesta ocasión ha hecho de acompañado. Parece, que no ha quebrado un plato en su vida; (†fuego!)

No fío en él, de él reniego. ¿Beato, rojo, y narigudo?

Si no me huele a rabudo, es porque huele a Gallego.

$$
2 .
$$

¿Gallego dixe? no es tal que de valenciano es hijo; mas que él es Gallego es fixo, y no lo digo por mal. Su vizarría tal qual lo desmiente, dirá alguno, Pero un refrán oportuno nos dice: „dime con quien? y pues sus tratos se ven de los Gallegos es uno.

Dexemos las décimas de pies libres, pues estos suelen dar libertad para decir más de lo que a veces se quiere, y vamos a las de pies atados, o forzados que 
aun assí sé mui bien, que no las han de coger por pies los Sres. Anticoplizantes tortugas. Las dos primeras son también como Prólogo a la respuesta.

\section{Décima $1{ }^{\circ}$}

Luego, que sabida — fue

tu maña de — concebir,

y del modo de — parir

vine a saber el por — qué;

raro capricho — engendré

de tu musa mal — cumplida;

si yo en la tuia - salida

ni entrada tube, ni — vi, ¿cómo la ofendes? a - ssi

esta mi Musa — sentida

\section{$2 .{ }^{a}$}

Si mi Musa de — lisiada

se quexó, todo su - mal

no fue para ti - fatal,

para mi si fue — maleada.

¿Mas que la tuia — preñada

de dicterios, y — torcida

tanto me aia — apurado

la Madre? este mal — preñado

tiene a mi Musa — sentida

Las siguientes seis décimas con los mismos pies forzados son respuesta a las dos, que a lo humano escribieron tan divinamente los Sres. Anticoplizantes.

$$
\text { 3. }{ }^{\text {" }}
$$

Si de ellos solo — fue

mi Romay el — concebir

serás al verte — parir

hermafrodita; con — que

debes decir — engendré

una mi imagen - cumplida,

y quien la vea _ salida

como quando ya la — vi, 
dirá: ella es tuerta en — sí como su Madre — sentida.

$$
4 .{ }^{\mathrm{a}}
$$

A Roma-y por todo — fue mi Romay por — concebir y no pudiendo — parir, solo abortó un no sé — qué. Yo mi concepto — engendré que especie buena, y — cumplida no pudo ser, ni — salida derecha le dio; bien — vi que su imagen parió — sí, mas contraecha, y - sentida.

$$
\text { 5." }
$$

Roma-y Italiano — fue en el nombre, y — concebir; y como se ve en - parir es Italiano; con — que puede decir: —— engendré aunque al revés mi — cumplida imagen, que aun fue —- salida a la contra; yo la - vi, que apestaba, siendo as - si Italiana con — sentida.

$$
6 .^{a}
$$

Mi pia Mater — lisiada es cierto, que pare — mal; mas no digas, que es — fatal en concebir, y - maleada; aun despues de estar — preñada es mui feliz; mas — parida toda su dicha es — torcida; pues tu mirar — apurado haze mal de ojo al — preñado; y haze a la Madre — sentida. 
Mi mollera está — lisiada

me escribes; mas este — mal

le padece bien — fatal

una de Roma-y _ maleada;

aunque siniestra — preñada

ya se vio, y aun mal - parida;

porque su prole - _ torcida

puso al útero — apurado;

y con tan tuerto - preñado

quedó su Madre — sentida.

\section{$8 .{ }^{2}$}

Si mi Madre es la — lisiada

no es mucho, que para - mal;

y mas quando es tan — fatal

su suerte por ti — maleada

Mas ella a solas - - preñada

se hizo, y se vió — parida,

lo que extraño es, que — torcida

esté la tuia, ___ apurada,

que hubo consorte al — preñado

y aun comadre con — sentida.

Carta que me escribieron los Sres. Anticoplizantes, ntelidos a Prosistas cultos. Toda ella se escribe a la letra, excepto los Parénthesis, que son como su respuesta. Guardo los originales por lo que pueda tronar. Dicen pues assí:

Mi amicmo. P. f.N. Un Yngenio, y medio (el Medio ingenio en Poesía bastaba para los dos, si no sc hicieran tanta merced) en esta Soledad (ni estaba tan solo, estando acompañado de un Ýngenio, que el otro medio se lo apropiaria para si el que escribia por no hazerse tanta merced a si proprio) acordandose de 15 Las Preñezes, y partos de $V, R m a$. también se pusieron a concebir y parieron (no señalan aquí el parto, que fue, sería algún monstruo, algún satyro, y alguna especie contrahecha, por hecha al trabés, o torcidamente, que algo de esto dan a entender en la causal siguiente) porque estas trabesuras, se hacen las mas de las vezes a escuritas, y sin candil. Si assi salio la obra (que assi salio como trabesura, a escuras, y sin candil) disculpe la V. Rma. (ya la dexo disculpada) que acaso nos saldrá otra mas manca (créolo sin que lo juren) si bien no sirva de 
exemplar para un torna, y buelve (no gusto yo de buelve, y de torna. Esso se queda para Roma-y Saboia, que es gente de Italia, y yo me precio de mui Español) que ni bolveremos ni tornaremos (ello dirá) porque acabamos solemnemente de hurtarle al grande Ovidio (a otro Nasones también, que son sus Mercedes Ladrones de primera clase de conceptos agenos) qual fue el de: iuro Pater nunquam componere versus (aunque no lo juren se les debe crédito, pues faltándoles numen mal podrán componere) lo que ratificamos en manos de V.P. como Padre (de tales hijos reniego) de quien son finissimos los Abbades de Flariz y Villamor. (al adjetivo finissimos pueden aplicar los sustantivos siguientes: de quien son finissimos emulos, finissimos burlones, finissimos perseguidores, y enemigos, etc). Pero hablando seriamente tengo muchas experiencias de que son mis finissimos amigos, componiéndose con esto el que sean mis finissimos anticoplizantes) Los que (dhos. Sres. Abbades) sienten no tener aqui las otras quatro décimas hechas por V.Rma. a la Sra. Prima, para que no quedasen sin un

15 vto. jaboncito a lo picaro (como son mis íntimos Amigos, no quiero darlos, ni el menor sentimiento, y assí les embiaré las quatro décimas, que dicen, para remedio de sus dolencias. Pero como se compone con esto, diciendo antes que no gustan de buelvo, y tomo, no tomandolo con el iuro iuro Pater etc? Esto es para que un hombre de bien se fíe de sus palabras y juramentos. Mas aquel sonsonete del jaboncito con el redoble: a lo pícaro me da golpe. ¿Qién metió a estos Sres. a lavanderas de agenas e imaginadas porquerías, teniendo sus Mercedes harto que hazer con las suias propias? guarden su jaboncito a lo pícaro (no podía ser otra casta de jabón) para limpiar sus cacas (las de sus coplas quiero decir pues en lo demás es gente mui limpia) Vale et iube. Villamor. 3 de henero.

Assi da fin la carta de los Sres. Anticoplizantes Prosistas y aunque la prosa de los Parenthesis pudiera servir de respuesta a su prosa, con todo esso voi a responderla por partes con los pies forzados de las otras.

Sobre aquellas cláusulas Un Yngenio, y medio en esta soledad, se pusieron a concebir, y parieron; porque estas trabesuras se hazen las mas de las veces a escuritas $y$ sin candil.

Permitaseme una cathegórica respuesta en décimas de pies libres, mientras vamos a las otras.

$$
\text { 9. }
$$

¿Que a concebir se pusieron

un Yngenio, y otro medio?

Por Dios causa horror, y tedio

oír, que el nefando hicieron 
¿cómo pues no les prendieron?

¿qué hizo la Inquisición?

¿dicen en su confesión

que son trabesuras? creo

segun trabiesos los veo

que ellos de Sodoma son.

$$
10 .^{8}
$$

¿Con que sin candil, y a obscuras

sus pecados cometieron

y aun sus ojos se cubrieron

por no ver tales basuras?

Mas jeómo sus trabesuras

(lo que me pasma esto es)

haciéndolas al través

assi las hari publicado?

¿y cómo es tan gran pecado

siendo pecado al revés?

Respóndese a las mismas cláusulas con los pies forzados.

\section{1.}

Que tan unidos los dos

hagais tales trabesuras

aunque sin candil y a obscuras

allá lo vereis con Dios.

¿Uno tras otro, o en pos?

¿Pues Valenciano no es

el uno, y mui coruñés

el otro? no, que es ficción;

que Roma-y Saboia* son

de Ytalia, gente al trabés.

$12 .^{\mathrm{*}}$

Un ingenio, y medio - fue

quienes mui bien — concebir

\footnotetext{
* Llámese uno Romay y atro Saboya
} 
han podido, y aun - parir

¿y en soledad? - ¿cómo qué?

No decís bien — engendré.

Lo de a obscuras mui — cumplida

noticia es, y aun — salida

sin luz; di pues: yo la — vi,

bien vista no, tuerta - sí

que tu vista assi es - sentida.

$13 .^{a}$

Que gran trabesura — fue me dices, el - concebir de tu Musa, y el — parir

a escuras; yo se el por — qué.

Bien dirás assi: —— engendré

aunque mi imagen — cumplida

mal entrada, y peor — salida;

trabiesa yo assi la - vi;

mas ¿qué maravilla — si

su madre assí esta — sentida...

\section{$14 .^{a}$}

¿Cómo no ha de ser — lisiada

tu Musa, pariendo — mal

si esse tu ojo — fatal

haze a la prole — maleada?

Aunque tu Musa — preñada

se ponga al verse — parida,

todos la han de ver - - torcida;

Y es que tu ojo - apurado,

sin miramiento — preñado,

tiene a su niña — sentida.

Sobre aquellas clausulas: acabamos solemnemente de hurtarle al grande Ovidio... acaso nos saldrá otra obra (Poética) más manca.

$$
15 .^{a}
$$

Que ladrón tu ingenio — fue confiesas; y al - concebir dicen te puso a - parir 

el hurto, no se por — qué.
Quando mi especie — engendré
(dices) otra más — cumplida
de Madres no fue — salida;
yo más manca la — vi;
pero no me espanto — si
es su madre assi — sentida

Sobre aquellas clausulas: los Abbades de Flariz y Montemar, sienten no tenes aqui las otras decimitas hechas a la prima.

$$
16 .^{\mathrm{a}}
$$

Vuestra Musa mui — lisiada

decis, que queda, y mui — mal;

siento golpe tan — fatal;

sanare lo — maleada.

El mal es que está — - preñada,

y la quereis ver — parida;

como no la hagais — torcida,

ya que me haveis — apurado,

Os embiare aquel — preñado

de mi Prima, aunque — sentida.

Sobre aquellas clausulas: no sirva de exemplar para un torna, y buelva, que ni torneremos, ni bolveremos.

¿De torna, y buelva no - fue

tu Musa, ni al — concebir?

a lo menos al — parir

rebolviste bien se — qué;

¿Quando dixiste — engendré

a lo Roma-y mui — cumplida

prole, no apestó — salida?

Ytaliana yo la — vi;

¿Madre, que retorna as — si

no es trabiesa con _ sentida? 
Sobre: el jaboncito a lo pícaro y es la última del certamen

$18 .^{\mathrm{n}}$

$$
\begin{aligned}
& \text { Tu Musa esta mui — lisiada } \\
& \text { padece mui grande — mal: } \\
& \text { el remedio, aunque — fatal } \\
& \text { es que sea bien — maleada } \\
& \text { con talega bien — preñada } \\
& \text { de piedras, y si — parida } \\
& \text { queda tu musa — torcida } \\
& \text { con jaboncito — apurada } \\
& \text { de Palencia, da al - preñado } \\
& \text { aunque se de por — sentida } \\
& \text { y es remedio aprobado. }
\end{aligned}
$$

Siguense las quatro decimitas, que deseaban ver a las manos los Sres. Anticoplizantes, para remedio de sus dolencias, y para darlas el jaboncito a lo pícaro. A su disposición las tienen, pueden jabonarlas a su salbo. Pero se les advierte, que por bien que las jabonen no las sacarán manchas, por negación del supuesto qui lotus est non indiget,ut lavetur. Sus jabonaduras, si que havrán de salir a la colada, quando buelvan a pasar por mi mano, asegurándoles, que llevarán una legía tan fuerte, y tan caliente, que les abrase vivos, aun a los mismos jabonantes.

\section{Redondilla}

La que es en todo primera, oigan, pues, que mete prima, es $\sin$ segunda tercera y aun es sin segunda Prima

Su glosa en quatro décimas:

$$
1 .^{a}
$$

Una Prima Dios me dio mui prima, en grado primero, y como assi me la quiero tal dicha Dios me paró.

Un sujeto reparó en que la llame tercera; 
dixe yo; estando el chiste en que el santo cordon viste la que es en todo primera

$$
2 .^{\mathrm{a}}
$$

¿Que ésta tan prima es tercera? ¿quién tal Señores pensara. que una de tan linda cara a Alcahueta se metiera? Pero Lector oie, espera que aunque tercera se exprima nunca terció assi mi prima: con el cordón si terció; ya mas de quatro arrastró digan pues que mete grima.

$$
\text { 3. }
$$

¿Es tercera sin segunda? esso yo no lo dixera de quien es en gran manera tan prima la rubicunda Persona divina infunda razon en mí, Dios lo quiera; ¿mas en amar no es primera la que es tercera? bien pues la que tan primera es es sin segunda tercera.

$$
4 .^{-9}
$$

Ya está dicho, Prima mía; que entre todas las mujeres prima sin segunda eres, llevando la prima mía. Lo de tercera, por pía y por el cordón se intima; por algo de maliciosa porque en esto es mui donosa $y$ aun es sin segunda prima. 
Dase fin a todo este Papel haciendo la salva a los dhos Sres. mis Paisanos, como la hize en un grande concurso, brindando a su salud, y hablando con los referidos Sres. Anticoplizantes, dixe de repente assí:

\section{Décima}

Digo, Señores Abbades, vivan alegres hufanas

las Sras, mis Paisanas con muchas felicidades, el que es en todo Maior mi Señor el Contador.

¿Contador? nadie desmienta

Pues que es páxaro de cuenta

todo el mundo es sabedor.

finis

et quid quid dixerim O.S.C.R.G. 